\title{
What Mathematics can do for Sustainability
}

\section{Simon Levin}

Published online: 24 October 2014

(C) Society for Mathematical Biology 2014

Ehrlich and Holdren (1971) proposed a very simple mathematical formula to express the negative impact of society on environment, namely

$$
I=P * F
$$

where $P$ is population size and $F$ is the per capita impact of each individual on the environment. Ehrlich and Holdren, in the midst of a debate with the environmentalist Barry Commoner, went on to elaborate this formula to the more familiar form

$$
I=P * A * T
$$

where $A$ is affluence and $T$ is technology. Such an equation, of course, is more a placeholder than a device for computation and analysis, but it foreshadowed the challenges that society faces today. How can our global society continue to enjoy the fruits of the Earth, in the face of a still-growing global population and increasing per capita demands, while assuring that future generations will still be able to enjoy high-quality lives? Some expectations, born perhaps of too much trust in technological advances, are that future generations will enjoy richer and richer lives; but, recognizing that the Earth's resources are finite, a more realistic but still difficult goal is to aspire for sustainability, the concept that future generations should at least have the same options that we enjoy (World Commission on Environment and Development 1987; Levin and Clark 2010).

The notion of sustainability has many dimensions, including but not limited to energy and natural resources, cultural and biological diversity, and the goods and

\footnotetext{
S. Levin ( ()

Princeton University, Princeton, NJ, USA

e-mail: slevin@princeton.edu
} 
services that we derive from Nature (Daily 1997). Classical economic approaches give short shrift to the social costs of individual actions and to the notion of natural capital; but, attitudes are changing. Arrow et al. (2004) ask whether we are consuming too much, evaluating intertemporal social welfare through the formula

$$
V(t)=\int_{t}^{\infty} U(C(s)) e^{-\delta(s-t)} d s
$$

where the utility $U$ is the social worth of the stream of consumption $C(s)$, discounted at the rate $\delta$. They go on to try to estimate $V(t)$ for various countries, with and without accounting for technological improvements, providing a framework for addressing sustainability. The goal is not, as is often the case, to maximize $V$, but rather to assure that it is not declining.

Equation (3) is just a beginning, a framework to begin addressing the issues of sustainability. Every part of the equation is open to debate, and every part is an object for research. For example, the discount rate itself-whether it should be positive, and indeed whether it even should be a constant-is crucial to how decisions are made, and is subject to heated debate that in part has to do with science, and in part has to do with ethics (Weitzman 2001; Arrow et al. 1996; Dasgupta 2008; Karp 2005).

The simple equations already mentioned help set an agenda for dealing with sustainability. Sustainability is, as Ehrlich and Holdren argue, about population growth, but also about the impacts of per capita consumption and about technology. It is, as Arrow et al. (2004) argue, about how we value the needs of future generations in relation to our own needs, about the social benefits and costs of our actions and consumption patterns, and about the role of technology. Managing for sustainability raises a suite of mathematical problems, from the dynamics of population growth and population interactions, to the development of sustainable energy sources, to the creation of management strategies for dealing with public goods and common-pool resources. Most of these problems and the mathematical methods that can help resolve them are unfamiliar fare in the pages of the Bulletin of Mathematical Biology, but hopefully this wonderful Special Issue will change that. The papers in this issue are of extremely high quality and introduce exciting problems, approaches and methods, many borrowed from other disciplines, that need the involvement of the readers of BMB, and are likely to stimulate much research that will help our societies achieve a sustainable future.

\section{References}

Arrow KJ, Cline WR, Mäler K-G, Munasinghe M, Squitieri R, Stiglitz JE (1996) Intertemporal equity, discounting, and economic efficiency. In: Bruce JP, Lee H, Haites EF (eds) Climate change 1995: economic and social dimensions of climate change, contribution of working group III to the second assessment report of the Intergovernmental Panel on Climate Change (IPCC). Cambridge University Press, Cambridge, pp 128-144

Arrow K, Dasgupta P, Goulder L, Daily G, Ehrlich P, Heal G, Levin S, Mäler K-G, Schneider S, Starrett D, Walker B (2004) Are we consuming too much? J Econ Perspect 18(3):147-172

Daily GC (ed) (1997) Nature's services: societal dependence on natural ecosystems. Island Press, Washington, p 392 
Dasgupta P (2008) Discounting climate change. J Risk Uncertainty 37:141-169

Ehrlich PR, Holdren J (1971) Impact of population growth. Science 171:1212-1217

Karp L (2005) Global warming and hyperbolic discounting. J Public Econ 89(2-3):261-282

Levin SA, Clark WC (eds) (2010) Toward a science of sustainability. Princeton University Printing and Mailing Services, Princeton. http://www.nsf.gov

Weitzman ML (2001) Gamma discounting. Am Econ Rev 91:260-271

World Commission on Environment and Development (1987) Our common future. Oxford University Press, New York 